\title{
ORIGIN OF MAFIC VOLCANICLASTICS IN THE CENTRAL PART OF THE TOUMODI-FETEKRO GREENSTONE BELT (CÔTE D'IVOIRE)
}

\author{
N'DRI EUDES SATI TEGAN ${ }^{1}$, KOUAKOU ALPHONSE \\ YAO $^{2}$, ALAIN NICAISE KOUAMELAN ${ }^{3}$, INZA \\ COULIBALY $^{4}$, PATRICK HAYMAN ${ }^{5}$, OUATTARA GBELE ${ }^{2}$ \\ AND WILDFRIED GISLAINE AKA ${ }^{2}$ \\ ${ }^{1}$ INP-HB \\ ${ }^{2}$ INPHB \\ ${ }^{3} \mathrm{UFHB}$ \\ ${ }^{4}$ Universite Nangui-Abrogoua \\ ${ }^{5}$ Queensland University of Technology \\ Presenting Author: ndrisati@gmail.com
}

Geodynamic models have listed ideas that the Birimian Gold Province is the result of subduction or rifting. The authors who have worked in this field have all shown the great diversity of formations that abounds the Birimian. In their studies, they just reported the presence of mafic volcaniclastics without giving more information about their origin. It is for this reason that this study was conducted to determine their origin. To do this, we used cartography, macroscopic and microscopic petrography and sedimentological analysis. All this has made it possible to define five lithofacies that are the coherent mafic and coherent felsic facies, the lava flow facies, the felsic volcaniclastic and volcanosediments and the mafic volcaniclastic facies. The facies of mafic volcanoclastics consist of pyroclastic fallout deposits, avalanche deposits, hyperconcentrated debris flow deposits and also river deposits. These formations would constitute the avalanche phase during the slide and the collapse stage of a volcanic structure. They are therefore epiclastics. 